\title{
Bilateral cataract and high serum ferritin: a new dominant genetic disorder?
}

Dominique Bonneau, Isabelle Winter-Fuseau, Marie-Noëlle Loiseau, Patrizia Amati, Michel Berthier, Denis Oriot, Carole Beaumont

\begin{abstract}
This paper reports the cosegregation in a three generation pedigree of dominantly inherited cataract with an abnormally high level of serum ferritin. In this family, circulating $L$ ferritin was raised in all subjects affected by cataract independently of iron overload. We suggest that a disorder of ferritin metabolism could be a new genetic disorder leading to lens opacity. Cataracthyperferritaemia syndrome could also be a new contiguous gene syndrome involving the $\mathbf{L}$ ferritin gene and the gene coding for the lens membrane protein (MP19), which both map to the same region of chromosome 19q.
\end{abstract}

(F Med Genet 1995;32:778-779)

A number of cataracts which develop during postnatal life (so-called "acquired" cataracts) can be attributed to metabolic defects which may impair lens transparency by interfering with lens metabolism. The lens opacity can be the result either directly of the disturbed lens metabolism (for example, G6PD deficiency) or the consequence of a pathologically increased or decreased serum constituent (for example, diabetes mellitus, galactosaemia, Wilson's disease). However, the metabolic disorder leading to lens opacity is still unknown in a number of cases. ${ }^{1}$

We report here a three generation pedigree in which patients affected by cataract were also found to have high serum ferritin levels without iron overload and we suggest that a disorder of ferritin metabolism could be a new genetic condition leading to cataract.

Service de Pédiatrie et Génétique, CHU de Poitiers, BP 577, 86021 Poitiers Cedex, France D Bonneau

I Winter-Fuseau

$M$ N Loiseau

P Amati

M Berthier

D Oriot

Unité INSERM U409, Génétique et

Pathologie Moléculaire de l'Hématopoièse,

Faculté de Médecine

Bichat, BP 416, 75870

Paris Cedex 8, France

C Beaumont

Correspondence to:

Dr Bonneau.

Received 14 February 1995 Revised version accepted for Revised version accepted
publication 6 June 1995

\section{Case report}

This three generation family was well known to ophthalmologists for the segregation of dominantly inherited bilateral cataract of early onset (figure). High levels of circulating ferritin were detected in all subjects affected by cataract (table) after this disorder had been discovered during extensive examination of the proband (IV.2), a female patient first examined when she was 6 years old for decreased visual acuity. At that time, white vacuolar deposits were found in both lenses. The loss in visual acuity slowly progressed and further ophthalmological investigations were performed when she was 10 years old. At this age, visual acuity was $3 / 10$ in the left eye and $6 / 10$ in the right eye. Slit lamp examination showed a deposit of dust-

\begin{tabular}{llll}
$\begin{array}{l}\text { Serum ferritin } \\
\text { and } L \text { ferritin levels }\end{array}$ \\
$\begin{array}{llll}\text { Family } \\
\text { members }\end{array}$ & Cataract & $\begin{array}{l}\text { Serum } \\
\text { ferritin }(\mu g / l)\end{array}$ & $\begin{array}{l}\text { Serum } L \\
\text { ferritin }(\mu g / l)\end{array}$ \\
\hline II·3 & & 2000 & 1680 \\
III·1 & + & 760 & ND \\
III.2 & + & 1236 & 1160 \\
III.3 & + & ND & 74 \\
IV·1 & - & ND & 18 \\
IV·2 & + & 2105 & 1480 \\
\hline
\end{tabular}

+ Affected by cataract.

- Normal lenses.

ND, not done.

like spots (pulverulent cataract) in all layers of both lenses. The lens deposit had an unusual orange coloured sheen which prompted us to test her iron metabolism. At that time, her extensive physical examination was normal.

Serum ferritin was $2105 \mu \mathrm{g} / 1$ (normal $20-300 \mu \mathrm{g} / \mathrm{l}$ ), serum iron $15 \mu \mathrm{mol} / 1$ (normal $10.5-25 \mu \mathrm{mol} / \mathrm{l}$ ), serum transferrin $3.73 \mathrm{~g} / 1$ (normal $2 \cdot 20-3 \cdot 80 \mathrm{~g} / 1$ ), transferrin iron binding capacity $60.9 \mu \mathrm{mol} / 1$ (normal $45-72 \mu \mathrm{mol} / 1$ ), and transferrin saturation was $25 \%$ (normal $20-50 \%$ ). Serum ferritin concentration was checked at least 10 times and increased values ranging from $1050 \mu \mathrm{g} / 1$ to $2700 \mu \mathrm{g} / 1$ were found each time whereas serum iron was in the normal range $(11 \cdot 4-15 \mu \mathrm{mol} / \mathrm{l})$. All other biochemical investigations were normal. The proband's father (III.2), also affected by cataract, was normal on clinical examination and, in particular, had no skin or mucosal pigmentation and no hepatomegaly. He was found to have a high serum ferritin level $(1236 \mu \mathrm{g} / \mathrm{l})$ contrasting with normal serum iron and normal transferrin iron binding capacity. Glucose tolerance was, however, diminished and preclinical diabetes mellitus was diagnosed. In view of the high serum ferritin level, a diagnosis of genetic

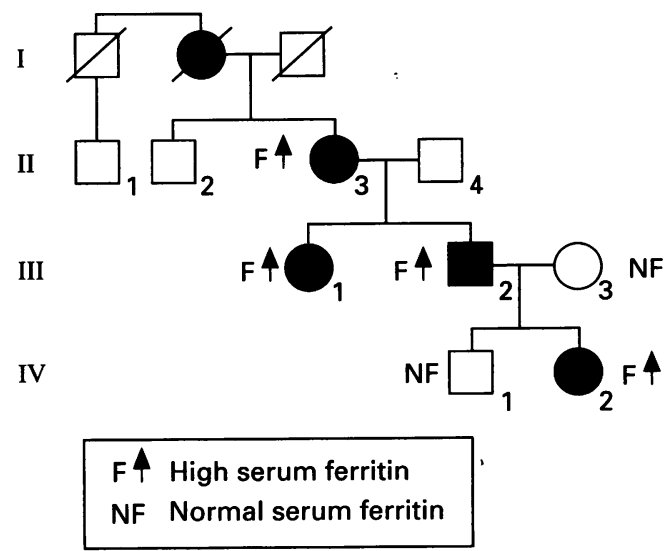

Pedigree of the family. 
haemochromatosis was suggested and a liver needle biopsy was performed. Microscopic examination of the liver showed no sign of cirrhosis but a heavy deposit of material of unknown nature was observed in the hepatocytes. Perls colouration showed only a slight iron deposit but, unfortunately, measurement of hepatic iron concentration was not done. Immunohistochemical studies of the liver biopsy using monoclonal anti-L ferritin antibodies showed strong staining in hepatocytes (data not shown), whereas only weak staining was obtained with anti-H ferritin antibodies. This strongly suggests that the deposit which was observed in hepatocytes corresponded to accumulation of $\mathrm{L}$ rich isoferritins. The proband's older brother (IV-1) was found to have normal lenses and had a normal serum ferritin level. The isotype of circulating ferritin was $\mathrm{L}$ type ferritin whereas no $\mathrm{H}$ type ferritin was detectable (Dr M Worwood, University of Wales College of Medicine) (table).

\section{Discussion}

In this three generation pedigree, the condition leading to lens opacity can be regarded as a direct consequence of a genetic defect whose mode of inheritance is autosomal dominant. Surprisingly, a significantly high serum ferritin concentration was found in all subjects with cataract whereas serum ferritin was normal in the subject with normal lens. The cosegregation of dominantly inherited cataract with an abnormally high level of serum ferritin has not, to our knowledge, been reported to date. Ferritin is the major iron storage protein in the cell and there is a close correlation between the serum ferritin concentration and the total iron content of the body. ${ }^{2}$ In the case of iron overload high plasma ferritin concentration is always found in the serum, associated with increased iron concentration and high transferrin saturation. In the present case, serum iron and transferrin saturation were found to be normal in at least two of our affected patients. This finding strongly supports the argument that in the present case circulating ferritin was raised independently of iron overload. However, the measurement of hepatic iron concentration was not performed on liver needle biopsy to rule out iron overload. Normal serum iron and normal transferrin saturation associated with dominant inheritance are also arguments against the diagnosis of genetic haemochromatosis, which is inherited as an autosomal recessive trait. It must also be noted that cataract has never been described as a clinical feature of idiopathic haemochromatosis. ${ }^{3}$

However, there are several situations in which plasma ferritin concentration may be inappropriately high without primary iron overload ${ }^{4}:$ (1) viral or drug induced hepatic damage, (2) infection, (3) inflammatory reaction and particularly adult Still's disease, ${ }^{5}$ (4) neoplasms. None of these conditions can be considered in this family and it appears probable therefore that the increase in circulating ferritin oberved occurred as a primary defect. This could represent a new genetic disorder involving ferritin metabolism, inherited as a dominant trait.

The ferritin molecule is made up of a 24 subunit protein shell surrounding an iron core in the form of ferric hydroxyphosphate. The subunits can be of two types named $\mathrm{H}(\mathrm{Mr}=$ $21000)$ and $\mathrm{L}(\mathrm{Mr}=19000)$, which can assemble in various proportions into the final ferritin molecule, thus generating a whole range of isoferritins. ${ }^{3}$ The origin of the circulating ferritin is still a matter of debate but the use of subunit specific antibodies in the radioimmunoassay showed that, in our family, the increase in serum ferritin levels that accompanies development of cataract corresponds mostly to an increase in $\mathrm{L}$ rich isoferritins. The synthesis of intracellular ferritin is regulated by iron through interaction between a cytoplasmic protein called "iron regulatory factor" (IRF) and a conserved motif present in the $5^{\prime}$ non-coding region of all ferritin mRNAs and called "iron responsive element" (IRE). When there is limited supply of iron to the cells, the IRF is bound to IRE and represses ferritin synthesis. It is tempting to speculate that a mutation in the DNA coding for the IRE of $\mathrm{L}$ ferritin or in the gene coding for IRF could impair the feedback regulation of ferritin synthesis by iron, thus leading to ferritin accumulation in the cells. How this would relate to the pathogenesis of cataract is not clear but modifications of iron turnover owing to an excess of ferritin could increase the production of reactive oxygen species and oxidative damage is known to be implicated in age related opacification of the lens.

On the other hand, the gene coding for L ferritin has been mapped to the long arm of chromosome 19 (19q13.3-19qter) ${ }^{6}$ and it is of interest to note that a gene (LIM2), coding for a major intrinsic protein of lens membrane (MP19), has also been mapped to the same region of chromosome 19 (19q13.4). ${ }^{7}$ LIM2 could therefore be responsible for cataract in the hypothesis of a contiguous gene syndrome.

In conclusion, cataract-hyperferritinaemia syndrome could be a new genetic disorder and we suggest that serum ferritin levels should be systematically assayed in all cases of dominant cataract.

1 Koch HR, Wegener A, Roth E. Anomalies of the lens. In: Emery AEH, Rimoin DL, eds. Principles and practice of medical genetics. 2nd ed. Edinburgh: Churchill Livingstone, 1990:669-82

2 Worwood $M$. Ferritin in human tissue and serum. Clin Haematol 1982;11:275-307.

3 Bothwell TH, Charlton RW, Motulsky AG. Hemochromatosis. In: Scriver CR, Beaudet AL, Sly WS, Valle $D$, eds. The metabolic basis of inherited disease. 6th ed. New York: McGraw-Hill, 1989:1433-62.

4 Jacobs A, Worwood M. Ferritin in serum. Clinical and biochemical implications. $N$ Engl f Med 1975;292:951-6.

Ota T, Higashi S, Suzuki H, Eto S. Increased serum ferritin levels in adult Still's disease. Lancet 1992;i:562-3.

6 Worwood M, Brook JD, Cragg SJ, et al. Assignment of human ferritin genes to chromosome 11 and 19q13.3-qter. Hum Genet 1985;69:371-4.

7 Lieuallen K, Christensen M, Brandriff B, Church R, Wang J, Lennon G. Assignment of the human lens fiber cell MP19 gene (LIM2) to chromosome 19q13.4, and adjacent to ETFB. Somat Cell Molec Genet 1994;20:67-9. 